\title{
POTENSI DAN ANALISA KELAYAKAN USAHA PENGOLAHAN MINYAK NILAM SEBAGAI ALTERNATIF PELUANG BERWIRAUSAHA DI KABUPATEN PASURUAN
}

\author{
Misbach Munir ${ }^{1)}$ Khafizh Rosyidi $^{2)}$ \\ ${ }^{1)}$ Fakultas Teknik Universitas Yudharta Pasuruan \\ Email : suratfakultas@gmail.com \\ ${ }^{2)}$ Fakultas Teknik Universitas Yudharta Pasuruan \\ Email: fakultasteknik@yahoo.co.id
}

\begin{abstract}
Abstrak
Berbicara tentang komoditas ekspor nonmigas, minyak atsiri dari nilam merupakan salah satu andalan. Bahkan negeri kita tercatat sebagai pengekspor minyak nilam terbesar di dunia. Meski populer di pasar internasional, anehnya minyak atsiri nilam kurang akrab di telinga kita. Apalagi masih sedikit yang mengenal sosok tanaman nilam dengan baik. Padahal ini peluang bisnis di masa depan. Komoditas nilam (Pogostemon cablin) merupakan tanaman yang menghasilkan minyak atsiri dengan nilai ekonomi di pasaran luar negeri sangat baik, mengingat negara penghasil komoditas ini hanya beberapa negara saja dan salah satunya yang terbesar adalah Indonesia. Dengan demikian pengembangan komoditas ini merupakan langkah strategis dalam menumbuh-kembangkan sektor agroindustri di Indonesia. Oleh karena itu budidaya tanaman nilam ini perlu diupayakan dengan dukungan teknologi pengolahan (destilasi) yang lebih efisien dan berkualitas agar mempunyai daya saing dan lebih efisien serta lebih ekonomis dibandingkan dengan sistem konvensional yang ada. Berdasarkan latar belakang di atas, maka rumusan masalah yang akan menjadi fokus penelitian ini, antara lain 1)Bagaimana teknik destilasi (penyulingan) yang dilakukan oleh unit usaha tani nilam di Desa Sekarmojo Kecamatan Purwosari Kabupaten Pasuruan.2)Apakah usaha pengolahan minyak di Desa Sekarmojo Kecamatan Purwosari Kabupaten Pasuruan nilam benar-benar merupakan komoditas yang menjanjikan secara financial. Dari table dan kurva peramalan permintaan produk dan penawaran harga di atas dapat disimpulkan bahwa selama 5 tahun ke depan dari tahun 2009 sampai tahun 2013 akan terjadi peningkatan permintaan produk dan penawaran harga produk sebesar $13,66 \%$ setiap tahunnya. Sedangkan penawaran harga juga menunjukkan adanya peningkata rata-rata sebesar 9,63\%. Untuk itu peluang usaha pengolahan minyak nilam ini memiliki peluang yang cukup besar ditinjau dari permintaan pasar. Berdasarkan evaluasi hasil perhitungan, dapat di ketahui jangka waktu pengembalian investasi pada usaha pendirian pngolahan minyak nilam ini adalah selama 1 tahun 5 bulan 18 hari, lebih kecil dari pada masa pengembalian investasi yang di tetapkan yaitu selama 5 tahun, sehingga di lihat dari analisa Payback Period (PP) dan Break Event Point (BEP) ini layak untuk di realisasikan
\end{abstract}

Kata Kunci : Minyak atsiri nilam, Destilasi, Payback Period, BEP, Kelayakan 


\section{PENDAHULUAN}

\section{Latar Belakang}

Berbicara tentang komoditas ekspor nonmigas, minyak atsiri dari nilam merupakan salah satu andalan. Bahkan negeri kita tercatat sebagai pengekspor minyak nilam terbesar di dunia. Meski populer di pasar internasional, anehnya minyak atsiri nilam kurang akrab di telinga kita. Apalagi masih sedikit yang mengenal sosok tanaman nilam dengan baik. Padahal ini peluang bisnis di masa depan. Komoditas nilam (Pogostemon cablin) merupakan tanaman yang menghasilkan minyak atsiri dengan nilai ekonomi di pasaran luar negeri sangat baik, mengingat negara penghasil komoditas ini hanya beberapa negara saja dan salah satunya yang terbesar adalah Indonesia. Dengan demikian pengembangan komoditas ini merupakan langkah strategis dalam menumbuh-kembangkan sektor agroindustri di Indonesia.

Menurut Dr. H. Roni Kastaman, Ir., MT., seorang peneliti dari LPM Dinas Koperasi dan UKM Jawa Barat, menyatakan bahwa hampir sekitar $90 \%$ pasokan minyak nilam dunia ( \pm 1.500 ton) adalah berasal dari Indonesia terutama dari daerah Propinsi Aceh. Namun dengan memburuknya situasi keamanan di Propinsi Aceh pada akhir-akhir ini, pasokan minyak nilam Indonesia juga ikut berkurang. Sehingga situasi ini membuka peluang bagi daerah-daerah lain di Indonesia untuk mengembangkan usaha komoditas ini. Minyak nilam mempunyai prospek usaha yang cerah mengingat komoditas ini di Amerika dan Eropa bisa mencapai harga USD (\$) 50 per kilogramnya, yang terutama dimanfaatkan sebagai bahan baku industri pembuatan minyak wangi (sebagai pengikat bau atau fixative parfum) dan kosmetik. Namun minyak nilam juga bisa dimanfaatkan untuk bahan anti-septik, antijamur, anti-jerawat, obat eksim dan kulit pecah-pecah, serta berbagai jenis kegunaan lainnya sesuai kebiasaan masyarakat di negara pemakai.

Di Jawa Timur, tanaman nilam telah dikembangkan di beberapa daerah seperti Kabupaten Malang dan Kabupaten Pasuruan, baik oleh swasta maupun melalui dukungan Dinas terkait (misalnya: Dinas Koperasi \& UKM dan Dinas Perindag) dengan pertumbuhan yang cukup memuaskan. Oleh karena itu budidaya tanaman nilam ini perlu diupayakan dengan dukungan teknologi pengolahan (destilasi) yang lebih efisien dan berkualitas agar mempunyai daya saing dan lebih efisien serta lebih ekonomis dibandingkan dengan sistem konvensional yang ada.

\section{Rumusan Masalah}

Berdasarkan latar belakang di atas, ada beberapa hal yang menjadi rumusan masalah yang akan menjadi fokus penelitian ini, antara lain :

1. Bagaimana teknik destilasi (penyulingan) yang dilakukan oleh 
unit usaha tani nilam di Desa Sekarmojo Kecamatan Purwosari Kabupaten Pasuruan?

2. Apakah usaha pengolahan minyak di Desa Sekarmojo Kecamatan Purwosari Kabupaten Pasuruan nilam benarbenar merupakan komoditas yang menjanjikan secara financial?

\section{Tujuan Penelitian}

Berdasarkan rumusan masalah di atas, maka tujuan penelitian ini adalah sebagai berikut :

1. Memberikan rekomendasi guna perbaikan teknis dan sistem penyulingan minyak nilam yang baik dan optimal bagi usaha tani nilam di Desa Sekarmojo Kecamatan Purwosari Kabupaten Pasuruan

2. Membuat analisa kelayakan finansial sebagai suatu pertimbangan dalam melakukan suatu perencanaan bisnis sesuai dengan pendekatan ilmiah untuk mewujudkan tata kelola usahatani pengolahan minyak nilam yang lebih baik

\section{KAJIAN PUSTKA}

\section{Pengertian Kelayakan Usaha}

Menurut Suad Husnan dan Suwarsono Muhammad (2000:4) : "Analisa Kelayakan adalah penelitian tentang dapat atau tidaknya suatu proyek (biasanya merupakan proyek investasi) dilaksanakan dengan berhasil". Yang dimaksud layak atau tidaknya disini adalah perkiraan bahwa proyek akan dapat atau tidak dapat menghasilkan keuntungan atau manfaat bila telah dioperasikan.

\section{Alat Ukur pada Kelayakan Usaha}

Alat ukur pada studi kelayakan ditentukan oleh beberapa aspek. Dalam studi kelayakan ditentukan aspek-aspek apa saja yang akan ditelaah. Dalam pembahasan ini ditekankan pada aspek pasar dan pemasaran, aspek teknis, aspek finansial dan aspek sosial ekonoi dan dampak lingkungan.

\section{Aspek Pemasaran}

Produk yang dihasilkan oleh wirausaha adalah barang atau jasa yang akan dipergunakan atau dibeli oleh masyarakat. Oleh sebab itu sebelum menentukan produk apa yang akan dihasilkan, maka seorang wirausaha harus mengetahui kondisi pasar terhadap barang dan jasa yang ditawarkan dan mengetahui kebutuhan permintaan dan penawaran, kejelasan informasi tentang- persaingan, informasi tentang perkembangan harga, saluran distribusi dan rencana pemasaran dari produk tersebut.

\section{a. Permintaan dan Penawaran}

Menurut konsep dari Dahl dan Hammond (1977), bahwa harga itu ditentukan oleh kekuatan permintaan dan penawaran yang bekerja di pasar. Permintaan menurut Kolter (1990) adalah keinginan akan produk yang spesifik yang didukung oleh kemampuan 
dan esediaan untuk membelinya. Kekuatan permintaan sangat bergantung pada harga.

\section{b. Pasar dan Analisis Persaingan}

Dahl dan Hammond (1977), pasar adalah sebagai suatu lingkungan atau ruang tempat kekuatan permintaan dan penawaran bekerja untuk menentukan atau memodifikasi harga sehingga terjadi pertukaran kepemilikan barang dan jasa serta adanya fakta kegiatan fisik dan institusional.Sedangkan menurt Kolter (2000), pasar terdiri dari semua pelanggan potensial yang mempunyai kbutuhan atau keinginan tertentu yang mungkin tersedia dan mampu melibatkan diri dalam suatu pertukaran guna memuaskan kebutuhan atau keinginan tersebut.

\section{c. Mengukur dan Meramal Permintaan}

Apabila perusahaan menemukan suatu pasar yang menarik, maka ia perlu mengestimasi besar pasarnya pada masa yang akan dating dengan cermat. Perusahaan akan kehilangan sejumlah laba karena terlalu besar atau terlalu kecil mengestimasi besarnya pasar.

Moving average pada suatu periode merupakan peramalan untuk satu periode ke depan dari periode rata-rata tersebut. Persoalan yang timbul dalam penggunaan metode ini adalah dalam menentukan nilai $\boldsymbol{t}$ (waktu) atau periode perata-rataan. Semakin besar nilai $t$ maka peramalan yang dihasilkan akan semakin menjauhi pola data. Secara matematis rumus fungsi peramalan metode ini adalah sebagai berikut.

$$
F_{t+1}=\frac{X_{i-N+1}+\ldots+X_{t+1}+X_{t}}{N}
$$

Dimana :

$$
\begin{aligned}
& X_{1}=\text { Data pengamatan periode } \mathrm{i} \\
& N=\text { Jumlah deret waktu yang } \\
& \text { digunakan } \\
& F_{t+1}=\text { Nilai peramalan periode } \\
& \mathrm{t}+1
\end{aligned}
$$

\section{Apek Teknis}

Aspek Teknis dan operasi merupakan lanjutan dari aspek pemasaran. Menurut Yacob Ibrahim (2003:118), aspek teknis adalah aspek yang berhubungan dengan pembangunan dari proyek yang direncanakan, baik dilihat dari faktor lokasi, luas produksi, penggunaan teknologi (mesin/peralatan) maupun keadaan lingkungan yang berhubungan dengan proses produksi.

\section{Penentuan Lokasi Usaha}

Penentuan lokasi usaha adalah suatu sikap yang lakukan untuk menentukan tempat di mana suatu perusahaan akan melakukan proses produksi. Penentuan lokasi usaha akan dihadapi oleh pengusaha pada saat baru atau akan mendirikan, me-relokasi atau akan melakukan expansi (memperluas usaha). Untuk menentukan lokasi yang akan digunakan sebagai tempat membangun fasilitas produksi yang dibutuhkan 
terdapat beberapa teknik/metode, antara lain :

\section{- teknik pembobotan faktor lokasi}

\section{(location faktoring technique)}

Untuk menggunakan metode ini prosedur yang perlu dilakukan adalah pertama dengan mengidentifikasi faktorfaktor yang dianggap penting untuk mengambil kputusan tentang lokasi. Kemudian setiap faktor diberi bobot yang nilainya mulai 0 (nol) samapi 1 (satu), di mana besarnya bobot tersebut mencerminkan tingkat kepentingan dari masing-masing faktor tersebut, dan dengan demikian faktor yang bobotnya lebih besar menunjukkan faktor tersebut lebih diperhitungkan dibandingkan dengan faktor lain yang nilai/bobotnya lebih kecil.

Langkah selanjutnya adalah menilai keadaan faktor-faktor yang dianggap penting sesuai dengan keadaan yang dianggap penting sesuai dengan keadaan yang ada pada setiap alternative lokasi. Besarnya nilai yang diberikan antara 0 sampai 100 untuk setiap faktor, tergantung dari kemenarikan faktor-faktor tersebut pada lokasi tertentu dibandingkan dengan lokasi yang lain dan kemudian seluruh nilai tersebut dikalikan dengan bobot dari masing-masing faktor. Jumlah nilai tertimbang dari setiap lokasi alternative menunjukkan tingkat kelayakan lokasi tersebut dibandingkan dengan yang lain.
Tabel 1. Metode Pembobotan Faktor Lokasi

\begin{tabular}{|l|c|c|c|}
\cline { 3 - 4 } \multicolumn{2}{l|}{} & Nilai & $\begin{array}{c}(\mathbf{0}- \\
\mathbf{1 0 0})\end{array}$ \\
\hline Faktor Lokasi & $\begin{array}{c}\text { Bobot } \\
(\mathbf{n})\end{array}$ & $\begin{array}{c}\text { Lokasi } \\
\mathbf{1} \\
(\mathbf{i})\end{array}$ & $\begin{array}{c}\text { Lokasi } \\
\mathbf{2} \\
(\mathbf{i i})\end{array}$ \\
\hline $\begin{array}{l}\text { Kedekatan } \\
\text { dengan bahan } \\
\text { baku }\end{array}$ & $\mathbf{0 , x x}$ & $\mathbf{x x}$ & $\mathbf{x x}$ \\
\hline $\begin{array}{l}\text { Kedekatan } \\
\text { dengan sumber } \\
\text { air }\end{array}$ & $\mathbf{0 , x x}$ & $\mathbf{x x}$ & $\mathbf{x x}$ \\
\hline $\begin{array}{l}\text { Kondisi jalur } \\
\text { transportasi }\end{array}$ & $\mathbf{0 , x x}$ & $\mathbf{x x}$ & $\mathbf{x x}$ \\
\hline $\begin{array}{l}\text { Kedekatan } \\
\text { dengan bahan } \\
\text { bakar }\end{array}$ & $\mathbf{0 , x x}$ & $\mathbf{x x}$ & $\mathbf{x x}$ \\
\hline $\begin{array}{l}\text { Kedekatan } \\
\text { dengan } \\
\text { konsumen }\end{array}$ & $\mathbf{0 , x x}$ & $\mathbf{x x}$ & $\mathbf{x x}$ \\
\hline $\begin{array}{l}\text { teknik pusat } \\
\text { gravity technique }) \\
\text { Teknik pusat }\end{array}$ & gravitasi & $($ center & of \\
\hline
\end{tabular}

dasarnya digunakan untuk menentukan pusat ditribusi yang melayani beberapa lokasi usaha dengan biaya distribusi yang paling rendah. Karena secara umum, besarnya biaya transportasi sangat tergantung dari dekat atau jauhnya jarak yang harus ditempuh, jumlah beban yang harus diangkut, dan waktu tempuh.

Titik koordinat untuk lokasi dari fasilitas yang baru dihitung dengan menggunakan rumus sebagai berikut :

$$
x=\sum\left(X_{i} W_{i}\right) / \sum W_{i}
$$

$$
Y=\sum\left(Y_{i} W_{i}\right) / \sum W_{i}
$$


Dimana :

$\mathrm{X}, \mathrm{Y}=$ Titik koordinat dari fasilitas yang baru pada puat gravitasi

$X_{1}, Y_{1}=$ Titik koordinat fasilitas yang

I yang ada

$W_{1}=$ Beban yang perlu

didistribusikan dari fasilitas

\section{Proses Produksi}

Menurut Schroeder (1990) ada 3 struktur aliran proses produksi yang dapat diplih oleh suatu perusahaan, yaitu proses produksi proyek, proses produksi intermitten dan proses produksi lini. Sedangkan menurut Krawjeski (1999) membedakan struktur aliran proses produksi yang merupakan satu kesatuan rangkaian yang dibagi menjadi 5, yaitu :

\section{1) Proses produksi proyek}

Proses produksi proyek adalah proses produksi yang tidak mempunyai urutan yang pasti, artinya urutan proses pembuatan produk untuk proyek yang satu berbeda dengan yaing lain. Proses produksi ini biasanya digunakan untuk membuat suatu proyek yang unik atau produk yang ukurannya besar dan berat, seperti jembatan, kapal laut, seni pertunjukan, dll.

2) Proses produksi borongan/pesanan ( $\mathrm{Job}$ Proces)

Proses produksi borongan adalah proses produksi yang dilakukan berdasarkan pesanan yang masuk dari konsumen sehingga perusahaan tidak akan memprduksi lebih awal. Proses poduksi ini dilakukan perusahaan bila kebutuhan spesifik konsumen yang akan datang tidak diketahui dan kemungkinan untuk memesan kembali sulit diperkirakan, sehingga akibatnya setiap pesanan baru akan ditangani sebagai unit tunggal (sebagai satu pekerjaan).

3) Proses produksi kelompok (Batch Process)

Perbedaan utama proses produksi kelompok dengan proses produksi lainnya adalah pada volume yang lebih besar karena pada proses produksi borongan produk atau jasa yang sama atau serupa akan dlakukan secara berulang-ulang.

4) Proses produksi garis (Line Proces) Proses produksi garis ini berada di antara proses produksi kelompok dan proses produksi kontineous. Pada proses produksi ini volume produksinya tinggi, dan produk atau jaa tertandarisasi, dimana sumber daya cadangan diorganisasikan disekitar produk atau jasa.

5) Proses produksi terus menerus (Contineous Proces)

Proses produksi teru menerus mempunyai volume produksi yang sangat tinggi, produksi yang terstandar dengan aliran garis yang kaku. Penamaan proses produksi teru menerus dibuat atas dasar aliran bahan baku selama proses. 


\section{Flow Chart/Diagran Alir Produksi}

Peta kerja adalah suatu alat yang digunakan untuk menggambarkan kegiatan kerja secara matematis dan jelas guna menganalisa proses kerja dari awal sampai akhir. Melalui suatu peta kerja kita dapat mengumpulkan informasiinformasi yang diperlukan untuk memperbaiki metode kerja. Hampir semua langkah atau kejadian dalam suatu proses akan terjadi elemen-elemen kerja seperti operasi, transportasi, pemeriksaan, menunggu dan menyimpan. Untuk maksud tertentu di atas digunakan berbagai macam simbol untuk menggambarkan masing-masing aktivitas.

Peta aliran produksi/operasi adalah peta kerja yang akan menggambarkan urutan kerja dengan jalan membagi pekerjaan tersebut menjadi elemenelemen operasi secara detail. Disini tahapan proses kerja harus diuraikan secara logis dan matematis. Akhir produk atau aktivitas sehingga analisa perbaikan dari masing-masing operasi kerja secara keseluruhan dapat dilakukan. Beberapa kegunaan dari pada peta proses operasi/produksi adalah sebagai berikut:

1) Mengetahui kebutuhan mesin dan peralatannya.

2) Sebagai alternatif untuk memperbaiki prosedur kerja yang sedang dijalankan.

3) Sebagai perbaikan metode yang telah dilaksanakan sehingga lebih efektif dan efisien.

\section{Penentuan Kapasitas Operasi}

Kapasitas operasi/pelayanan harus relevan dengan poteni pasar dan prediki permintaan, sehingga tidak terjadi kelebihan atau kekurangan sumberdaya untuk jasa pelayanan sehingga tercapai keuntungan yang optimal.

\section{Bahan Baku}

Kegiatan perusahaan mempunyai hubungan yang sangat erat dengan kegiatan produksi. Perusahaan mengadakan kegiatan produksi untuk memenuhi kebutuhan pasar. Untuk mengadakan kegiatan produksi harus ada bahan baku. Oleh karena itu di dalam dunia usaha masalah bahan baku merupakan masalah yang sangat penting. Agar jangan sampai terjadi keterlambatan bahan baku, maka harus diadakan penentuan persediaan bahan baku secara baik. Persediaan bahan baku sebagai kekayaan perusahaan memiliki peranan penting di dalam operasi bisnis dalam pabrik" (Yamit, 1998 : 216). Bahan baku merupakan faktor utama di dalam perusahaan untuk menunjang kelancaran proses produksi, baik perusahaan dalam perusahaan besar maupun perusahaan kecil.

Cara penyelenggaraan persediaan bahan baku berbeda-beda untuk setiap perusahaan, baik dalam jumlah unit persediaan bahan baku yang ada dalam perusahaan, waktu penggunaannya, maupun jumlah biaya untuk membeli 
bahan baku tersebut. Paling sedikit ada tiga alasan perlunya persediaan bahan baku bagi perusahaan, yaitu (Yamit, 1998 : 216): 1) Adanya unsur ketidakpastian permintaan (permintaan yang mendadak), 2) Adanya unsur ketidakpastian pasokan dari supplier, 3) Adanya unsur ketidakpastian tenggang waktu.

Untuk menghadapi ketiga unsur ketidakpastian tersebut, pihak perusahaan harus mampu mengantisipasinya. Antisipasi tersebut berkaitan erat dengan tujuan diadakannya persediaan bahan baku, yaitu (Yamit, 1998: 216):

1) Untuk memberikan layanan yang terbaik pada pelanggan,

2) Untuk memperlancar proses produksi,

3) Untuk mengantisipasi kemungkinan terjadinya kekurangan persediaan (stock out),

4) Untuk menghadapi fluktuasi harga.

\section{Aspek Organisasi dan Manajemen}

Yang dinilai dalam aspek ini adalah para pengelola data usaha dan truktur organisasi yang ada. Proyek yang dijalankan akan berhasil apabila dijalankan oleh orang-orang yang professional, mulai dari merencanakan, melaksanakan sampai dengan mengendalikannya agar tidak terjadi penyimpangan. Dmikian pula dengan struktur organisasi yang dipilih harus dengan bentuk dan tujuan usahanya. Bentuk-bentuk dari organisasi: a. Organisasi Line/Garis

Organisasi lni adalah organisasi yang semata-mata memiliki hubungan wewenang lini dalam organisasinya. Organisasi seperti ini merupakan bentuk organisasi yang berskala kecil dengan sedikit jumlah karyawan yang belum atau sedikit memiliki spesialisasi.

b. Organisasi Lini dan Staff

Tipe organisasi seperti ini, asas kesatuan komando tetap dipertahankan. Pelimpahan wewenang berlangsung secara vertical dan sepenuhnya dari pimpinan tertinggi kepada unit bawahanya.

c. Organisasi Fungsional Organisai fungional disusun berdasarkan sifat dan macam-macam fungi yang harus dilaksanakan. Masalah pembagian kerja mendapat perhatian yang sungguh-sungguh. Pucuk pimpinan mendelegasikan wewenang kepada manajer dibawahnya dan meneruskannya kepada pelaksana, hanya mengenai tuga-tuga tertentu saja. Dengan demikian para bawahan akan mendapat perintah dari beberapa atasannya yang masing-masing menguasai suatu keahlian tertentu dan bertanggungjawab sepenuhnya atas bidangnya masing-masing.

\section{d. Organisasi Lini Staff dan Fungsional} Organisasi ini merupakan kombinasi dari ketiga tipe, yaitu: organisasi lini, staff dan fungsional. Tipe ini biasanya diterapkan pada organisai besar dan 
kompleks, pada tingkat dewan direksi diterapkan tipe organisasi lini dan staff, sedangkan pada tingkat madya diterapkan tipe organisasi fungsional.

\section{Aspek Hukum}

Dalam aspek ini yang akan dibahas adalah masalah kelengkapan dan keabsahan dokumen perusahaan, mulai dari bentuk badan usaha ke ijin-ijin yang dimiliki.

Bagi peneliti studi kelayakan usaha, dokumen yang perlu diteliti keabsahan, kesempurnaan dan keasliannya meliputi badan hokum, ijin-ijin yang dimiliki, sertifikat tanah dan dokumen lainnya yang mendukung kegiatan tersebut. Kegagalan dalam aspek ini akan berakibat tidak sempurnanya hasil penelitian atau dengan kata lain apabila ada dokumen yang tidak sah dan tidak sempurna pasti akan menimbulkan masalah dikemudian hari.

Dalam pendirian usaha ini terdapat beberapa perjanjian yang harus dilalui, yaitu :
a. Surat permohonan
b. KTP pemimpin
c. Akte pendirian perusahaan dari notaries setempat (bagi yang berbadan hukum)
d. Nomor Waib Pajak Pereorangan dari kantor pajak setempat (NPWP)
e. Surat Ijin Tempat Usaha (SITU)
f. Surat keterangan lokasi

\section{Aspek Finansial}

Dalam studi kelayakan suatu usaha yang perlu diperhatikan dan dipertimbangkan adalah bagaimana seorang pengusaha dapat mengambil keputusan berapa minimal perusahaan harus berproduksi agar tidak mendapat kerugian. Investasi yang dilakukan dalam berbagai bidang usaha, sudah barang tentu memerlukan sejumlah modal (uang), disamping keahlian lainnya. Untuk pertama kali modal digunakan untuk biaya pra-investasi dan aktiva tetap seperti, pengurusan ijin-ijin, pembelian tanah, pendirian bangunan atau gedung, pembelian mesin-mesin sampai dengan biaya operasi pada saat usaha tersebut dijalankan. Besarnya modal untuk investasi yang diperlukan tergantung dari jenis usaha yang akan dijalankan. Perhitungan terhadap besarnya kebutuhan investasi yang perlu dilakukan sebelum investasi dilakukan.

Untuk memenuhi kebutuhan investasi, modal dapat dicari dari berbagai sumber dana yang ada. Sumber dana yang dicari dapat dipilih, apakah dengan modal sendiri atau modal pinjaman.

Penelitian dalam aspek ini dilakukan untuk menilai biaya-biaya apa saja yang akan dihitung dan seberapa besar biayabiaya yang akan dikeluarkan.

a. Biaya dan Pendapatan

1. Biaya Investasi

Dalam menentukan jumlah dan investasi secara keseluruhan disesuaikan dengan aspek teknis produksi : 
a. Tanah, luas tanah yang diperlukan disesuaikan dengan luas tanah yang diperlukan dalam aspek teknis, baik untuk bangunan gedung, kantor, gudang dan lain sebagainya. Jumlah dana yang diperlukan untuk pengadaan tnah disesuaikan dengan harga yang berlaku.

b. Gedung, gedung yang diperlukan dalam hal ini adalah untuk bangunan pabrik, kantor, gudang dan lain sebagaiya. Untuk menilai biaya gedung untuk bangunan pabrik tergantung paa aspek produksi, apakah satu lantai atau dua lantai, hal ini disesuaikan dengan proses produksi.

c. Mesin, mesin yang digunakan juga diesuaikan dengan aspek produksi apaka menggunakan mesin yang mempunyai teknologi tinggi atau tidak. Bermacam-macam mesin yang dipakai dalam proses produksi tentu telah dinilai dalam aspek produksi.

d. Peralatan, untuk memenuhi biaya peraltan, diesuaikan dengan jenis dan jumlah peralatan yang diperlukan dan dihitung dalam haga yang berlaku.

e. Biaya lainnya, seperti biaya peralatan lain yang berhubungan dengan pengembangan proyek.

\section{Biaya Operasional}

Biaya operasional adalah biaya yang dikeluarkan untuk membayar kewajibanyang harus dibayar selama mengoperasikan usaha. Biaya yang harus dikeluarkan antara lain: upah tenaga kerja, pembayaran rekening listrik, telephon, dan biaya pemelharaan selama operasi berlangsung.

3. Pendapatan Sebelum Pajak (Earning Before Tax/EBT)

EBT adalah pendapatan yang diperoleh dari penjualan produk atau jasa kemudian dikurangi dengan biaya operasional yang dikeluarkan.

4. Pendapatan Sedudah Pajak (Earning After Tax/EAT)

EAT adalah EBT dikurangi pajak penghasilan. Dalam penilaian investasi, pendapatan yang dipakai dalam perhitungan adalah pendapatan setelah pajak (EAT).

b.Depresiasi

Untuk menjaga kontinuitas kegiatan usaha dari proyek yang direncanakan perlu dihitung besarnya biaya penyusutan pada setiap tahun. Sebuah perusahaan yang sehat pada umunya mempunyai cadangan penyusutan/depresiasi untuk menjaga kontinuitas dari kegiatan usaha disamping menjaga kualitas serta untuk memudahkan dalam mengikuti perubahan asset dengan adanya perubahan teknologi. 
1) Perhitungan Bunga

2) Pajak Penghasilan

3) Komponen Aliran Kas

4) AnalisaKriteria

Adapun metode yang dapat digunakan untuk mengetahui apakah investasi yang akan dilakukan layak atau tidak adalah dengan menggunakan metode payback period. Metode payback period adalah suatu periode yang diperlukan untuk menutup kembali pengeluaran investasi dengan menggunakan aliran kas (cash flow).

Metode payback period ini merupakan rasio antara initial cash investment dan cash flow yang hasilnya merupakan satuan waktu. Selanjutnya nilai rasio ini dibandingkan dengan maximum payback period yang dapat diterima.

Untuk itu yang biasanya dilakukan oleh banyak pengusaha sukses adalah dengan menggunakan analisis titik impas (break event point). Analisis break event point (BEP) adalah analisis sederhana untuk membuat keputusan manajerial tanpa melakukan penelitian secara rumit. Dalam analisis ini manajer/seorang pengusaha hanya cukup mendapatkan sedikit data seperti biaya tetap, biaya variable, dan haga jual. (Yogi: 2004).

Selain dengan menggunakan pendekatan analisis BEP, Yogi (2004), juga memberikan alternalif pendekatan lain dengan menggunakan analisi Time
Series. Di mana analisis Time Series ini adalah analisis untuk meramalkan nilai yang akan datang dengan bantuan dari data-data sebelumnya.

BEP terjadi pada titik persilangan antara garis penghasilan penjualan dan garis total biaya.

Rumus matematika untuk menentukan BEP adalah :

$$
\begin{array}{cc} 
& \text { Total Biaya Tetap } \\
\cline { 2 - 2 }(\mathrm{REP})= & 1-\frac{\text { Total Biaya }}{\text { Variabel }} \\
& \begin{array}{c}
\text { Total Biaya } \\
\text { Penjualan }
\end{array} \\
\text { BEP } & \text { Total Biaya Tetap } \\
(\text { unit })= & \begin{array}{c}
\text { Harga jual/unit }- \\
\text { Biaya variable/unit }
\end{array}
\end{array}
$$

\section{Aspek Sosial Ekonomi dan Dampak Lingkungan}

Dalam menjalankan usahanya seorang usahawan harus melakukan analisis dampak lingkungan (ANDAL) dan analisis sosial (ANSOS), agar mudah beradaptasi dengan lingkungan usahanya dan lebih lanjut untuk menjaga kelangsungan usahanya. ANDAL dan ANSOS sangat dibutuhkan oleh pengusaha dalam membuat perencanaan usaha dalam bentuk apapun. Analisis ANDAL dan ANSOS merupakan suatu hal yang sangat berpengaruh besar terhadap lingkungan dimana seorang pengusaha akan membuka tempat usahanya dan sekaligus membuat dan menentukan strategi perencanaan dalam pengambilan keputusan. 


\section{METODOLOGI PENELITIAN}

\section{Rancangan Penelitian}

Untuk mendapatkan data yang sesuai maka dilakukan strategi mengatur lokasi penelitian agar diperoleh data yang valid sesuai dengan karakteristik variable dan tujuan penelitian.

Tabel 2. Rancangan Penelitian

\begin{tabular}{|l|l|}
\hline Uraian & Penjelasan \\
\hline Sumber data & $\begin{array}{l}\text { Data primer dan data } \\
\text { sekunder }\end{array}$ \\
\hline Pendekatan riset & Survey \\
\hline Instrumen riset & $\begin{array}{l}\text { Interview, } \\
\text { dokumentasi dan } \\
\text { observasi }\end{array}$ \\
\hline Pengolahan data & $\begin{array}{l}\text { Uji adanya peluang } \\
\text { dan uji kelayakan }\end{array}$ \\
\hline $\begin{array}{l}\text { Menghitung aspek } \\
\text { financial }\end{array}$ & $\begin{array}{l}\text { Payback Period dan } \\
\text { BEP }\end{array}$ \\
\hline
\end{tabular}

\section{Daerah Penelitian}

Penelitian dilakukan dengan menggunakan metode studi kasus di industri pengolahan minyak nilam milik Kelompok Tani Nilam yang berlokasi di Desa Sekarmojo, Kecamatan Purwosari, Kabupaten Pasuruan, Jawa Timur..

\section{Jenis dan Sumber Data}

Data yang akan dikumpulkan dalam penelitian ini meliputi data primer dan sekunder. Data primer dalam penelitian ini berupa pendapat, penilaian, dan aspirasi responden terhadap kegiatan kerja di lingkungan perusahaan. Sedangkan data sekunder dalam penelitian ini meliputi data-data yang terkait dengan proses produktifitas, perencanaan produksi dan pengendalian persediaan.

\section{Data}

Data adalah informasi yang berupa angka tentang karakteristik (cir-ciri kasus) suatu populasi. Data pada penelitian ini berupa data primer dan data sekunder.

\section{Populasi}

Populasi adalah keseluruhan unit yang menjadi obyek kegiatan penelitian. Populasi dalam penelitian ini adalah seluruh bagian dari unit usaha tani pengolahan minyak nilam termasuk para petani nilam di Desa Sekarmojo Kecamatan Purwosari Kabupaten Pasuruan dan badan-badan yang terkait dengannya.

\section{Sampel}

Sampel adalah sebagian unit populasi yang menjadi obyek penelitian untuk memperkitakan karakteristik suatu populasi. Sampel dalam penelitian ini adalah unit-unit usaha tani nilam di Desa Sekarmojo Kecamatan Purwosari Kabupaten Pasuruan dan badan-badan yang terkait dengannya yan pernah mengikuti kegiatan yang berkaitan dengan proses produktifitas yang sama.

\section{Responden}

Responden adalah orang yang ditentukan sebagai obyek kegiatan pengumpulan data. Responden dalam penelitian ini adalah para petani nilam di Desa Sekarmojo Kecamatan Purwosari Kabupaten Pasuruan. 
Diagram Alir Peneitian

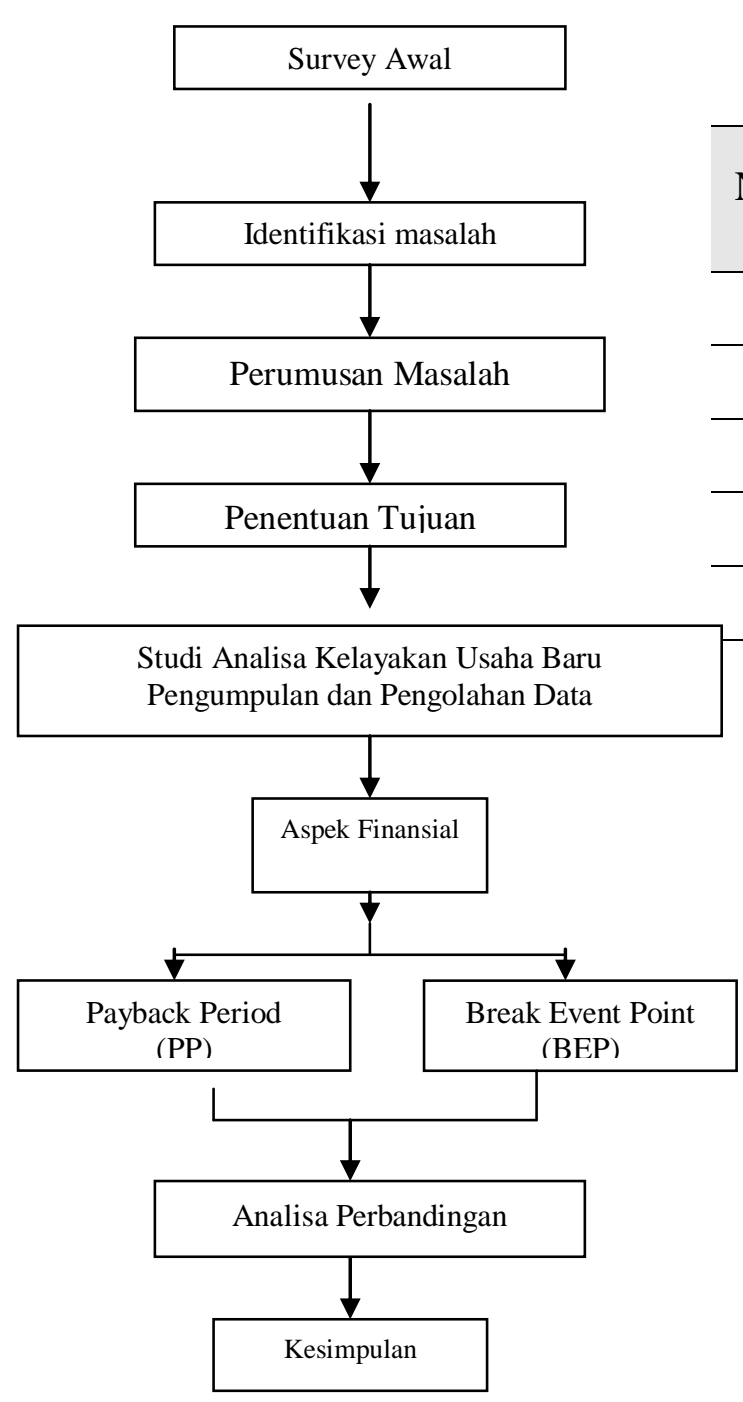

\section{HASIL DAN PEMBAHASAN}

\section{Peramalan Permintan Minyak Nilam}

Perhitungan Pengukuran dan

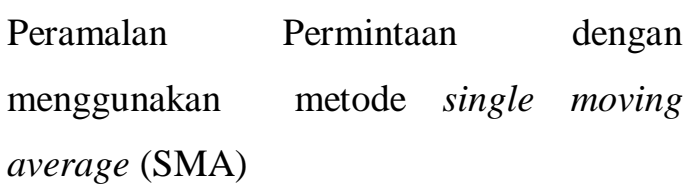

Tabel 3.

Peramalan Permintaan Produk dan Penawaran HargaTahun 2009-2013

\begin{tabular}{c|c|c|c}
\hline No & Tahun & $\begin{array}{c}\text { Jumlah (Ton) } \\
(x)\end{array}$ & $\begin{array}{c}\text { Nilai (Rp) } \\
(s)\end{array}$ \\
\hline 1 & 2009 & 2.354 & 57.582 .000 \\
\hline 2 & 2010 & 2.857 & 66.799 .000 \\
\hline 3 & 2011 & 3.277 & 73.600 .000 \\
\hline 4 & 2012 & 3.741 & 83.792 .000 \\
\hline 5 & 2013 & 4.311 & 96.202 .000 \\
\hline
\end{tabular}

Persentase rata-rata kenaikan/tahun :

$$
\begin{aligned}
& \bar{x}=\frac{68,3}{5}=13,66 \% \\
& \bar{s}=\frac{48,14}{5}=9,63 \%
\end{aligned}
$$

Dari table dan kurva peramalan permintaan produk dan penawaran harga di atas dapat disimpulkan bahwa selama 5 tahun ke depan dari tahun 2009 sampai tahun 2013 akan terjadi peningkatan permintaan produk dan penawaran harga produk sebesar $13,66 \%$ setiap tahunnya. Sedangkan penawaran harga juga menunjukkan adanya peningkata rata-rata sebesar 9,63\%. Untuk itu peluang usaha pengolahan minyak nilam ini memiliki peluang yang cukup besar ditinjau dari permintaan pasar. 
Kelayakan Finansial

Kebutuhan Modal

\section{1) Modal Investasi}

Modal investasi pada usaha pengolahan minyak nilam ini menggunakan modal milik pengusaha sendiri. Pengambilan tingkat bunga yang diinginkan (Cost of Capital) adalah 15\%.

Tabel 4. Perhitungan biaya investasi

\begin{tabular}{r|l|c|r|r}
\hline No & \multicolumn{1}{|c|}{ Keterangan } & $\begin{array}{c}\text { Jumlah } \\
\text { (Unit) }\end{array}$ & \multicolumn{1}{|c}{$\begin{array}{c}\text { Harga Awal } \\
\text { (Rp) }\end{array}$} & \multicolumn{1}{|c}{ Total (Rp) } \\
\hline 1 & Bahan Baku & $2400 \mathrm{Kg}$ & 8.000 & 1.920 .000 \\
\hline 2 & Sewa kendaraan ditribusi & $1 \mathrm{th}$ & 450.000 & 2.250 .000 \\
\hline 3 & Rental mesin suling & $1 \mathrm{th}$ & 150.000 & 750.000 \\
\hline 4 & Bahan bakar kayu & $5 \mathrm{~m}^{3}$ & 100.000 & 500.000 \\
\hline 5 & Karung ukuran besar & 100 & 5.500 & 550.000 \\
\hline 6 & Jurigen & 5 & 30.000 & 150.000 \\
\hline 7 & Timbangan & 1 & 750.000 & 750.000 \\
\hline
\end{tabular}

Tabel 5. Perhitungan Depresiasi

\begin{tabular}{l|r|r|r|l|r|r}
\hline \multicolumn{1}{c|}{ Item } & $\begin{array}{c}\text { Harga } \\
\text { awal }\end{array}$ & $\begin{array}{c}\text { Jumlah } \\
\text { (Unit) }\end{array}$ & $\begin{array}{c}\text { Umur } \\
\text { Ekonomis }\end{array}$ & $\begin{array}{l}\text { Perkiraan } \\
\text { Nilai Sisa }\end{array}$ & $\begin{array}{c}\text { Depresiasi/ } \\
\text { tahun }\end{array}$ & Nilai Akhir \\
\hline Bahan Baku & 8.000 & 2400 & 2 & 5.000 & 1.500 & 12.000 .000 \\
\hline Bahan bakar kayu & 100.000 & 5 & 3 & 75.000 & 25.000 & 75.000 \\
\hline Karung ukuran besar & 5.500 & 100 & 4 & 3.500 & 500 & 3.500 \\
\hline Jurigen & 30.000 & 5 & 5 & 15.000 & 3.000 & 15.000 \\
\hline Timbangan & 750.000 & 1 & 2 & 500.000 & 125.000 & 500.000 \\
\hline \multicolumn{2}{c|}{ Total } & & & $\mathbf{1 5 5 . 0 0 0}$ & $\mathbf{1 2 . 5 9 3 . 5 0 0}$ \\
\hline
\end{tabular}

Tabel 6. Biaya Pemeliharaan

\begin{tabular}{c|c}
\hline Tahun & $\begin{array}{c}\text { Biaya Pemeliharaan } \\
\text { (Rp) }\end{array}$ \\
\hline 2009 & 600.000 \\
\hline 2010 & 630.000 \\
\hline 2011 & 661.500 \\
\hline 2012 & 694.575 \\
\hline 2013 & $729.303,75$ \\
\hline
\end{tabular}

Tabel 7. Biaya Overhead

\begin{tabular}{c|c|c|c}
\hline \multirow{2}{*}{ Tahun } & \multicolumn{2}{|c|}{ Biaya } & \multirow{2}{*}{ Total (Rp) } \\
\cline { 2 - 3 } & Pemeliharaan (Rp) & Telephon (Rp) & \\
\hline 2009 & 600.000 & 600.000 & 1.200 .000 \\
\hline 2010 & 630.000 & 630.000 & 1.260 .000 \\
\hline 2011 & 661.500 & 661.500 & 1.323 .000 \\
\hline 2012 & 694.575 & 694.575 & 1.389 .150 \\
\hline 2013 & $729.303,75$ & $729.303,75$ & $1.458 .607,5$ \\
\hline & \multicolumn{3}{|c}{} \\
\hline
\end{tabular}




\section{Penilaian Investasi}

Metode penilaian investasi yang digunakan adalah : Payback Period (PP) dan Break Event Point (BEP).

\section{a. Payback Period}

Perhitungan Payback Period dapat dilihat pada table berikut :

\begin{tabular}{|c|c|c|}
\hline Tahun & $\begin{array}{c}\text { Kas Bersih } \\
(\mathbf{R p})\end{array}$ & Total \\
\hline Investasi & -6.870 .000 & -6.870 .000 \\
\hline 2009 & 14.741 .000 & 7.871 .000 \\
\hline 2010 & 80.991 .000 & 88.862 .000 \\
\hline 2011 & 128.645 .300 & 217.597 .300 \\
\hline 2012 & 203.302 .595 & 420.809 .895 \\
\hline 2013 & $321.642 .553,8$ & $742.452 .448,8$ \\
\hline $\begin{array}{c}\text { Nilai } \\
\text { Akhir }\end{array}$ & 12.593 .500 & 755.045 .948 .8 \\
\hline
\end{tabular}

$$
\begin{aligned}
\mathrm{PP}= & 1+\frac{6.870 .000}{14.741 .000} \times 12 \text { bulan } \\
& =1 \text { tahun }+(0,466 \times 12 \text { bulan }) \\
& =1 \text { tahun }+5 \text { bulan }+(0,593 \times 30 \text { hari }) \\
& =1 \text { tahun } 5 \text { bulan } 18 \text { hari }
\end{aligned}
$$

Berdasarkan perhitungan di atas, maka dapat dikeahui jangka waktu pengembalian investasi pada usaha pengolahan minyak nilam ini adalah selama 1 tahun 5 bulan 18 hari, lebih kecil dari masa pengembalian investasi yang ditetapkan yaitu selama 5 tahun, sehingga dilihat dari analisa Payback Period proyek ini layak untuk direalisasikan.
b.Break Event Point

$B E P_{\text {unit }}=$

$$
\begin{aligned}
& \frac{\text { BiayaTetap }}{H \arg \text { aJual / unit }- \text { BiayaVaria bel / unit }} \\
& =\frac{\operatorname{Rp} 6.630 .757,5}{\operatorname{Rp} 250.000-\operatorname{Rp~} 8.000} \\
& =\frac{\operatorname{Rp~6.630.757,5~}}{\operatorname{Rp} 242.000}=27,5 \text { liter minyak }
\end{aligned}
$$

$$
B E P_{R_{p}}=
$$

$$
\begin{array}{r}
\frac{\text { BiayaTetap }}{1-\frac{\text { BiayaVariabel / unit }}{H \arg \text { aJual / unit }}} \\
=\frac{R p 6.630 .757,5}{1-\frac{R p 8.000}{R p 250.000}} \\
=\text { Rp. } 6.849 .956
\end{array}
$$

\section{KESIMPULAN}

1. Usaha pengolahan minyak nilam Di Desa Sekarmojo Kecamatan Purwosari Kabupaten Pasuruan ini adalah usaha tani pengepul bahan baku minyak nilam yakni yang berupa tanaman nilam kering. Minyak nilam merupakan salah satu jenis minyak atsiri yang dapat dihasilkan dari tanaman nilam yang diperoleh melalui proses distilasi atau proses penyulingan tanaman nilam kering.

2. Berdasarkan evaluasi hasil perhitungan, dapat di ketahui jangka waktu pengembalian investasi pada usaha pendirian pngolahan minyak nilam ini adalah selama 1 tahun 5 bulan 18 hari, lebih kecil dari pada masa pengembalian 
investasi yang di tetapkan yaitu selama 5 tahun, sehingga di lihat dari analisa Payback Period (PP) dan Break Event Point (BEP) ini layak untuk di realisasikan.

\section{SARAN}

Kelompok petani supaya mendirikan unit distilasi secara mandiri, karena berdasarkan hasil perhitungan dan analisa perbandingan dengan menggunakan metode Payback Period (PP) dan Break Event Point (BEP) menunjukkan nilai positif secara finansial sehingga proyek layak untuk direalisasikan.

\section{DAFTAR PUSTAKA}

Badan Pusat Statistik, Oktober 2004,Statistik Perdagangan Luar Negeri Indonesia

Buffa, Elwood S.Rakesh K Sarin. 1999. Manajemen Operasi dan Produksi

Gittinger, 1986, Analisa ekonomi proyekproyek pertanian. Edisi kedua, UI Press Jakarta

Ginting Rosnani 2009, Sistem Produksi, Penerbit Graha Ilmu Jakarta

Kusuma Hendra 2009, Manajemen Produksi, Penerbit Andi Yogyakarta

Miranty, 2005, Rencana Usaha yang Rasional, Yayasan Bina Karsa Mandiri Jakarta

Maria dan Naning, 2007, Analisa Kelayakan Usaha, Penerbit Guna Ilmu

Nasution,Arman.H 2005, Manajemen Industri.Penerbit Andi Yogyakarta
Sayuti, 2008, Analisa Kelayakan Pabrik, Penerbit Graha Ilmu

Pusat Penelitian dan Pengembangan Perkebunan, 2007 Bogor, Teknologi Unggulan Nilam

Wignjosoebroto, Sritomo.1989. Teknik Tata Cara Dan Pengukuran Kerja. ITS Surabaya 